\begin{tabular}{|c|c|}
\hline $\begin{array}{c}\text { European Association for the } \\
\text { Development of Renewable Energies, Environment } \\
\text { and Power Quality (EA4EPQ) }\end{array}$ & $\begin{array}{c}\text { International Conference on Renewable Energies and Power Quality } \\
\text { (ICREPQ'12) }\end{array}$ \\
Santiago de Compostela (Spain), 28th to 30th March, 2012
\end{tabular}

\title{
Analysis of an infrared burner working with hybrid fuel: LPG / bio-oil
}

\author{
Oliveira, Breno Costa Correa ${ }^{2}$. Azevedo Neto, Aluisio ${ }^{1}$. Fontes, Francisco de Assis Oliveira ${ }^{2}$. Barbosa, Cleiton \\ Rubens Formiga ${ }^{2}$. Filho, Franklin Rocha de Azevedo \\ ${ }^{1}$ Companhia Potiguar de Gás \\ POTIGÂS \\ Avenida Branca Dunas, 485, Candelária - CEP 59064-720 - Natal/RN (Brasil) \\ Phone: +55 84 88599643, e-mail: aluazevedo@uol.com.br \\ ${ }^{2}$ Universidade Federal do Rio Grande do Norte - UFRN. Campus Universitário - Lagoa Nova \\ CEP 59072-970 - Natal/RN - Brasil \\ Phone: +55 84 88829334, e-mail: brenocorrea@gmail.com, franciscofontes@uol.com.br, cleiton@ufrnet.br
}

\begin{abstract}
From the pyrolysis of biomass is possible to obtain bio-oil with higher energy density and better use properties. The use of infrared burners has many advantages, for example, uniformity in the heat in the form of radiation and convection. This paper presents a commercial infrared burner adapted with an ejector proposed to burn a hybrid configuration of liquefied petroleum gas (LPG) and bio-oil diluted. The dilution of bio-oil with absolute ethanol aimed to decrease the viscosity of the fluid, and improving the stability and atomization. It was introduced a temperature controller with thermocouple modulating two stages and solenoid valves for fuels supply. The infrared burner has been tested and evaluated its performance by conducting energy balance. The method of thermodynamic analysis to estimate the load was used an aluminum plate and the distribution of temperatures measured by thermocouples. The dilution reduced the viscosity and increased the lower heating value (LHV), providing a stable combustion to the burner through the atomizing with compressed air and burns combined with LPG. Injecting the hybrid fuel there was increase in the heat transfer from the plate to the environment and gain useful benefit, due to the improved in the efficiency of the infrared burner.
\end{abstract}

\section{Key words}

Infrared burner, atomizer, liquefied petroleum gas, biooil, energy balance

\section{Introduction}

In the last century, fuels derived from petroleum were the worldwide main sources of energy. Nowadays, with the increase in oil demand, there is need to develop an economic process for the sustainable production of fuels and chemicals, inserted within the political and environmental concerns about the use of fossil fuels [1]. This need for alternative energy sources has increased interest in the use of biomass, because it is a renewable fuel capable to reduce emissions of $\mathrm{CO}_{2}$ and sulfur. In this context, Brazil is the largest world producer and consumer of "bioenergy" [2]. The high rates of biomass use in Brazil are related to factors such as climatic diversity and abundance of agroforestry resources [3].

The use of biomass as a potential source of automotive fuels, chemical products and materials has given new impetus to the practice of pyrolysis in the last two decades, stands out as one of the most promising technologies for conversion into liquid fuels [4]. The control of some parameters of pyrolysis results in different products such as liquid and solid material, which can have varied applications [5].

Pyrolysis is a thermal conversion process that involves the rupture of carbon-carbon bonds and the formation of carbon-oxygen bonds. The proportion of gaseous products, liquid and solid formed depends on the control of some process parameters [6]. The resultant liquid of this process is traditionally called bio-oil [5].

Aiming a study concerning the use of bio-oil as fuel, through the efficiency valuation of the 1st Law of Thermodynamics, was used an infrared burner with macroporous ceramic bed coupled to a control and feeding semi-automatic system to accomplish the joint firing of bio-oil with liquefied petroleum gas (LPG).

The combined use of LPG allows the bio-oil to be burned more easily, because the gas and the infrared burner allows the involved temperatures in combustion reaches values close to $800{ }^{\circ} \mathrm{C}$. This is explained by Howell [7], who says that the insertion of a high emissivity ceramic structure causes the mixture of oxidizer and fuel is preheated before the reaction zone, promoting an 
increase in the rate of chemical reaction, increasing the maximum temperature in the reaction zone, reaching values above the flame adiabatic temperature and lower emissions.

The dilution of bio-oil with absolute ethyl alcohol has the main objective the reduction of fluid viscosity, and improvement of stability and atomization. Diebold [8] made a review of physical mechanisms and chemical stability of bio-oil and showed that the addition of solvents such as methanol and ethanol, improve its stability and decreases its viscosity.

\section{Materials and Methods}

\section{A. Production of raw material}

The bio-oil used was supplied by the UFRN's Laboratory of Biomass and Biofuel, obtained from fast pyrolysis of biomass made with sawdust. The process involves the injector of biomass in the pyrolysis plant, with a fluidized bed reactor operating at about $500{ }^{\circ} \mathrm{C}$, where the reaction occurs. After the fast pyrolysis, products are obtained as coal and pyrolysis gases. By gravity, the coal falls into tanks and the gases follow, where they are subjected to a "washing" to remove small impurities, and after condensation, is transformed into bio-oil used in this study.

\section{B. Bio-oil Dilution}

One of the problems with the bio-oil was the high viscosity, in addition to rapid aging and polymerization.

It was decided to begin dilution with $10 \%$ absolute ethanol, growing at around $5 \%$ until a maximum percentage of $25 \%$ for the mixture. It was observed that with percentages below $25 \%$ were unable to obtain a complete homogenization of the bio-oil. Thus, it was adopted standard dilution of $25 \%$ in all tests performed in this work. This fuel was initially named as BO25.

\section{BO25 Storage}

The BO25 was filtered through a paper filter. Thus, it was removed some impurities and / or sludge still present in the fuel. After filtering, the fuel was stored in clear glass beaker at room temperature, under light and closed to avoid contact with atmospheric air.

\section{Description of Test Bench}

Figure 1 illustrates the schematic diagram of the infrared burner together with the equipment and instruments used during the tests and their respective locations.

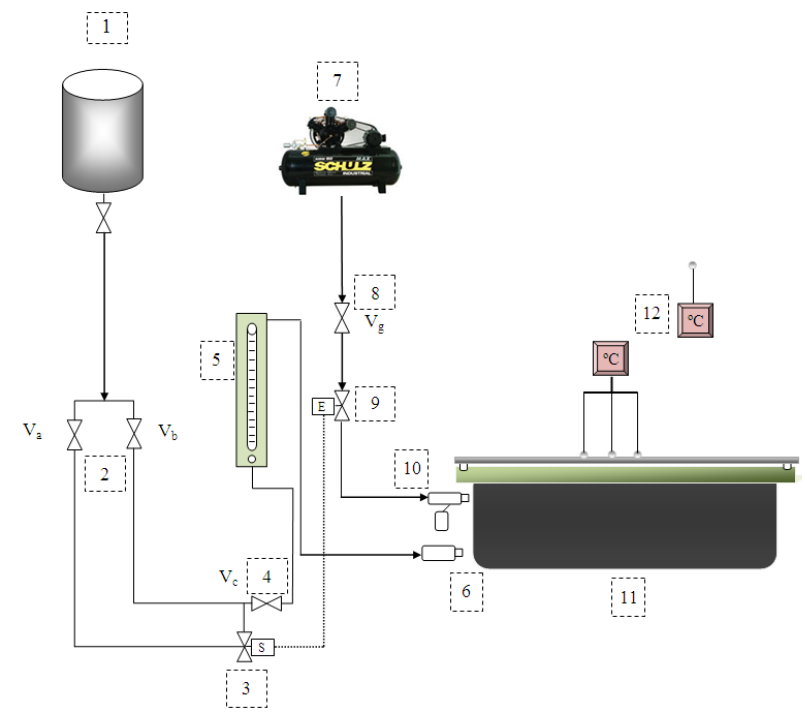

Fig. 1. Diagram of equipment used to carry out the burning of the hybrid fuel

Table I. Description of the Equipments

\begin{tabular}{|c|c|}
\hline Number & Description \\
\hline 1 & $\begin{array}{c}\text { Heat source }-13 \text { kg commercial LPG gas } \\
\text { cylinder }\end{array}$ \\
\hline 2 & $\begin{array}{c}\text { Control system of the burner flame - Manifold } \\
\mathrm{V}_{\mathrm{a}}-\text { Needle valve for high flame (high flow) } \\
\mathrm{V}_{\mathrm{b}}-\text { Needle valve for low flame (low flow) }\end{array}$ \\
\hline 3 & $\begin{array}{c}\text { Solenoid valve that operates in the feed system } \\
\text { of LPG gas }\end{array}$ \\
\hline 4 & $\mathrm{~V}_{\mathrm{c}}-$ On/off valve (opening/closing) \\
\hline 5 & Rotameter for measuring the flow of GLP \\
\hline 6 & $\begin{array}{c}\text { LPG injector nozzle - equipment responsible for } \\
\text { inserting the LPG gas in the burner }\end{array}$ \\
\hline 7 & $\begin{array}{c}\text { Air compressor working with operation pressure } \\
\text { of 300 kPa }\end{array}$ \\
\hline 8 & $\begin{array}{c}\mathrm{V}_{\mathrm{g}} \text { - Needle valve for regulating the compressed } \\
\text { air }\end{array}$ \\
\hline 9 & $\begin{array}{c}\text { Electro-valve that operates in the compressed air } \\
\text { supply system }\end{array}$ \\
\hline 10 & $\begin{array}{c}\text { Air/BO25 injector nozzle - equipment } \\
\text { responsible for inserting the atomized mixture } \\
\text { of air and BO25 in the burner }\end{array}$ \\
\hline 11 & Infrared burner \\
\hline 12 & Thermocouple for temperature measuring \\
\hline
\end{tabular}

\section{E. Infrared Burner}

It was used a $6.1 \mathrm{~kW} \mathrm{Jackwal}{ }^{\circledR}$ infrared burner (Fig. 2). The burner was manufactured by forming of a carbon steel plate shaping a metallic housing. The housing is coated (enameled) with a layer of crushed glass and has the following dimensions: $170 \mathrm{~mm}$ wide and $405 \mathrm{~mm}$ in length.

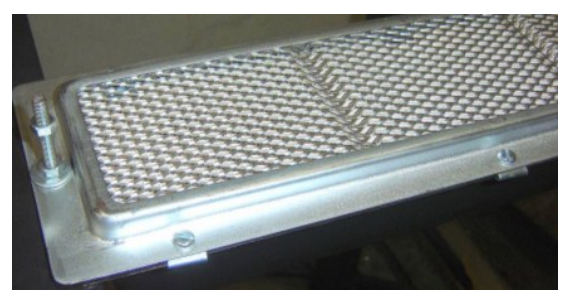

Fig. 2. Infrared burner 


\section{F. Injector Nozzles}

It was used a Jackwal ${ }^{\circledR}$ injector nozzle, with a 1.4 mm hole (Fig. 3), and an air/BO25 injector nozzle that it was fully developed on UFRN's Energy Laboratory (Fig. 4). It was used a Leepro Tools ${ }^{\circledR}$ airbrush equipped with a reservoir and a regulator of liquid propellant to insert properly the $\mathrm{BO} 25$ in the burner. The compressed air line connected to airbrush works at a pressure of $300 \mathrm{kPa}$.

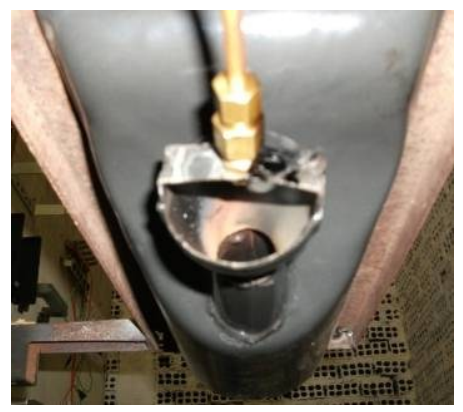

Fig. 3. LPG injector nozzle

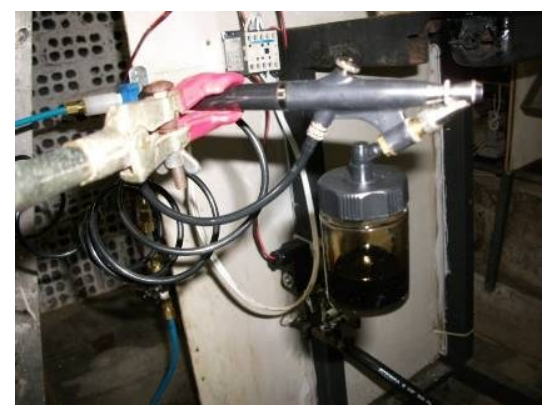

Fig. 4. Compressed air/BO25 injector nozzle

\section{G. Maximum Temperature Limiter System and Fuel Block}

To allow the control of the maximum temperature to be reached, it was used a digital controller/indicator of temperature manufactured by Tholz ${ }^{\circledR}, \mathrm{MDH}-\mathrm{P} 299$ model (Fig. 5) with range from 0 to $300{ }^{\circ} \mathrm{C}$ in series with a relay manufactured by Telemecanique ${ }^{\circledR}$, CA2KN model, responsible for triggering the solenoid valve and electro-valve which functions to block the flow of fuel when it reached $270{ }^{\circ} \mathrm{C}$ at the surface of an aluminum plate.

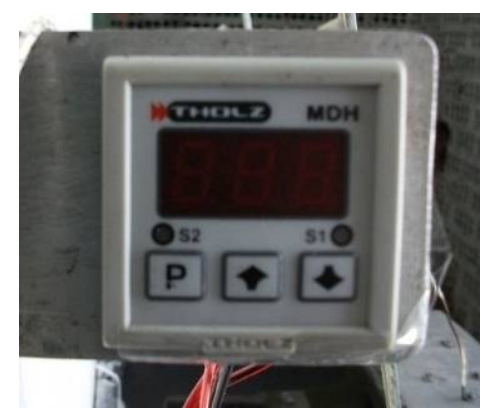

Fig. 5. Digital controller/indicator of temperature

One solenoid is responsible for blocking the injection of compressed air from $\mathrm{BO} 25$ feed system when it reaches the maximum temperature determined from $270{ }^{\circ} \mathrm{C}$ and another solenoid valve (Parker ${ }^{\circledR}$ model DT-1908), connected to a manifold (set of LPG's flow regulating valves), partially blocks the flow of LPG (regulating high heat / low heat) when the burner reaches the same temperature. Therefore, these valves are activated simultaneously (Fig. 6 and Fig. 7).

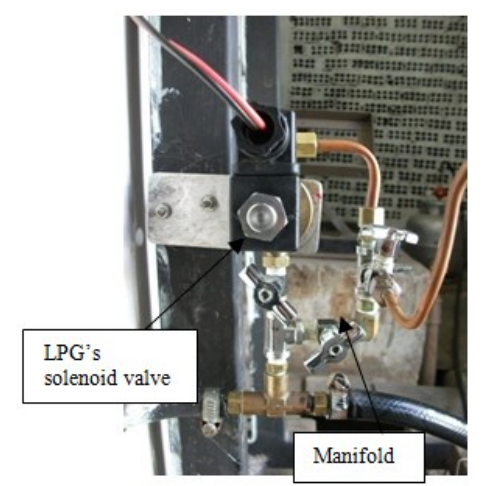

Fig. 6. Solenoid valve

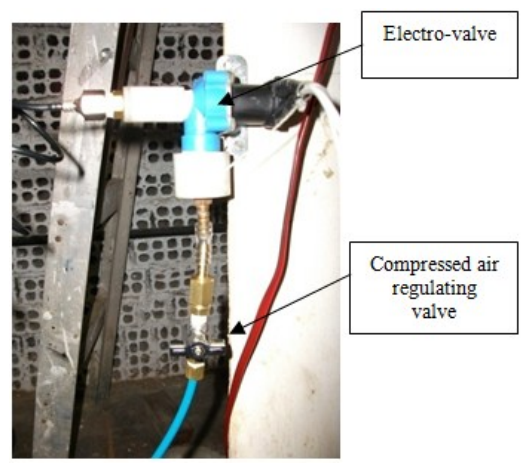

Fig. 7. Blocking hybrid fuel electro-valve

\section{H. Temperature Measurement System}

One of the most important parameters for determining the thermal energy in thermal systems is the temperature, which was a major focus of this study to evaluate the performance of the burner. Were installed four type $\mathrm{K}$ thermocouples for the measurements of temperatures $\left({ }^{\circ} \mathrm{C}\right)$. Three thermocouples were installed in the center of the aluminum plate and the latter in the laboratory for measurement of ambient temperature.

In these tests, the temperature measurements were performed by monitoring and annotation of the temperatures involved in the process, the time was controlled by a precision digital stopwatch.

\section{Tests Description}

The test was started from the ignition of the infrared burner through a pilot light in the LPG's gas injector nozzle. The heat from the exhaust gas was transferred to the aluminum plate (heat sink) by convection and radiation. 
The behavior of the heating profile was monitored by a temperature gauge attached to the aluminum plate, until it reaches the set point on the controller.

When is reached the steady state of operation, in other words, when there is no more significant variation in temperature, it is started the injection of $\mathrm{BO} 25$ in the infrared burner. From this moment, the simultaneous measurements of LPG consumption $(\mathrm{mL} / \mathrm{min})$ and $\mathrm{BO} 25$ $(\mathrm{mL} / \mathrm{min})$ were performed.

\section{J. Measuring Systems for LPG and BO25}

There are several techniques to determine the flow of a fluid. In the specific case of this work, was chosen to use the measurement of volumetric flow of LPG with a rotameter and use a precision digital stopwatch to control the flow time of high and low flame, when the infrared burner is operating at steady state.

The BO25's flow rate was measured simultaneously with LPG, using a $25 \mathrm{~mL}$ glass pipette calibrated to measure the volume. The flow time was monitored using a precision digital stopwatch, with the infrared burner operating at steady state. For this operation, was used the reservoir of the airbrush.

With the $\mathrm{BO} 25$ injector in full operation, was recorded the volume variation in elapsed time of the measurement. Allied to this measurement, was used a precision digital balance in order to obtain a second analysis of the mass variation of burned $\mathrm{BO} 25$.

Was conducted the measurement of volumetric flow of LPG and BO25's container, in three bench tests considering a time of ten minutes. Subsequently, was calculated the mass flow rate through the specific mass of each fuel. Also, was calculated the arithmetic average and standard deviation of the three taken samples from each one.

\section{Results and Discussion}

\section{A. Viscosity Test of Bio-oil and BO25}

The viscosity tests were performed at the UFRN's Laboratory of Technology of Surfactants I using a rheometer. In the tests was considered the time of 300 seconds, by measuring 10 different points, where the first three points were not considered because they are null values. Table II shows the values for the bio-oil, where the average value for the viscosity was $40.92 \mathrm{cP}$.

Table II. Viscosity values for the bio-oil

\begin{tabular}{|c|c|c|c|}
\hline Point & $\begin{array}{c}\text { Test time } \\
(\mathrm{s})\end{array}$ & $\begin{array}{c}\text { Shear rate } \\
(1 / \mathrm{s})\end{array}$ & $\begin{array}{c}\text { Shear stress } \\
(\mathrm{mPa})\end{array}$ \\
\hline 1 & 120 & 0.00252 & 0.0996 \\
\hline 2 & 150 & 0.00283 & 0.114 \\
\hline 3 & 180 & 0.00328 & 0.133 \\
\hline 4 & 210 & 0.00348 & 0.155 \\
\hline 5 & 240 & 0.00426 & 0.177 \\
\hline
\end{tabular}

\begin{tabular}{|c|c|c|c|}
\hline 6 & 270 & 0.00513 & 0.204 \\
\hline 7 & 300 & 0.00585 & 0.235 \\
\hline Point & $\begin{array}{c}\text { Viscosity } \\
(\mathrm{cP})\end{array}$ & $\begin{array}{c}\text { Temperature } \\
(\mathrm{K})\end{array}$ & $\begin{array}{c}\text { Torque } \\
(\mu \mathrm{Nm})\end{array}$ \\
\hline 1 & 39.50 & 300.32 & 14.76 \\
\hline 2 & 40.48 & 300.31 & 16.96 \\
\hline 3 & 40.51 & 300.3 & 19.72 \\
\hline 4 & 44.45 & 300.3 & 22.93 \\
\hline 5 & 41.50 & 300.3 & 26.21 \\
\hline 6 & 39.79 & 300.28 & 30.27 \\
\hline 7 & 40.21 & 300.33 & 34.88 \\
\hline
\end{tabular}

Table III shows the values for $\mathrm{BO} 25$, where the average value for viscosity was $10.06 \mathrm{cP}$.

Table III. Values for BO25 viscosity

\begin{tabular}{|c|c|c|c|}
\hline Point & $\begin{array}{c}\text { Test time } \\
(\mathrm{s})\end{array}$ & $\begin{array}{c}\text { Shear rate } \\
(1 / \mathrm{s})\end{array}$ & $\begin{array}{c}\text { Shear stress } \\
(\mathrm{mPa})\end{array}$ \\
\hline 1 & 120 & 0.00223 & 0.02114 \\
\hline 2 & 150 & 0.0025 & 0.0269 \\
\hline 3 & 180 & 0.00292 & 0.03209 \\
\hline 4 & 210 & 0.00363 & 0.03693 \\
\hline 5 & 240 & 0.00428 & 0.04181 \\
\hline 6 & 270 & 0.00476 & 0.04748 \\
\hline 7 & 300 & 0.00562 & 0.05258 \\
\hline Point & $\begin{array}{c}\text { Viscosity } \\
(\mathrm{cP})\end{array}$ & $\begin{array}{c}\text { Temperature } \\
(\mathrm{K})\end{array}$ & $\begin{array}{c}\text { Torque } \\
(\mu \mathrm{Nm})\end{array}$ \\
\hline 1 & 9.47 & 27.06 & 3.133 \\
\hline 2 & 10.67 & 27.05 & 3.986 \\
\hline 3 & 11.00 & 27.07 & 4.757 \\
\hline 4 & 10.17 & 27.06 & 5.474 \\
\hline 5 & 9.76 & 27.04 & 6.197 \\
\hline 6 & 9.97 & 27.07 & 7.037 \\
\hline 7 & 9.35 & 27.07 & 7.793 \\
\hline
\end{tabular}

Thus, from the dilution of bio-oil with $25 \%$ of absolute ethyl alcohol was possible to reduce the viscosity at $75.4 \%$, also reducing the polymerization reactions and improving the atomization of $\mathrm{BO} 25$ in the proposed injector nozzle.

\section{B. Heating Value Test of Bio-oil and BO25}

The heating power tests were performed in UFRN's Laboratory of Applied Thermodynamics. Before entering the bio-oil and $\mathrm{BO} 25$ in the bomb calorimeter, we followed the procedure of the laboratory, and conducted sample heating at $50{ }^{\circ} \mathrm{C}$ for 1 minute, to remove any water droplets.

Through testing with the bomb calorimeter was possible to find the higher heating value of bio-oil and BO25. The results were $16.759 \mathrm{~kJ} / \mathrm{kg}$ for the bio-oil, and 18.483 $\mathrm{kJ} / \mathrm{kg}$ for $\mathrm{BO} 25$.

From the dilution, the higher heating value was increased by about $10 \%$ compared to the bio-oil, with a very limited change in this feature.

From Eq. (1), we calculated the lower heating value of bio-oil and $\mathrm{BO} 25$. For the bio-oil, the value was 15.341 $\mathrm{kJ} / \mathrm{kg}$ and the $\mathrm{BO} 25$ was $17.065 \mathrm{~kJ} / \mathrm{kg}$, ie, an increase of about $11 \%$. 


$$
L H V=H H V-218.13 \times H
$$

Where LHV is lower heating value (in $\mathrm{kJ} / \mathrm{kg}$ ), HHV is higher heating value (in $\mathrm{kJ} / \mathrm{kg}$ ) and $\mathrm{H}$ is percentage of the mass of hydrogen in the fuel (\%).

\section{Measured Temperatures}

Two points of temperature measurement were used to verify the heat transfer of aluminum plate for the environment. The one point was obtained from three thermocouples connected to the aluminum plate and the point two from a thermocouple to measure ambient temperature.

From the analysis of recorded temperatures was observed that temperatures were higher, when it was injected $\mathrm{BO} 25$ in the infrared burner, also with an increase in the rate of heating of the aluminum plate due to the use of hybrid fuel.

Temperatures measured on the plate produced very similar values, and the ambient temperature in all trials remained constant.

Considering the methodology used, it was found that the heating value decreased with the addition of $\mathrm{BO} 25$ in the fuel mass flow. We also observed that the transient temperature increased with the inclusion of hybrid fuel.

The first test, shown in Fig. 8, performed only with LPG, allowed the aluminum plate to be heated to $231^{\circ} \mathrm{C}$, showing a transient temperature (between the temperature of the aluminum plate and the ambient temperature) equal to $203^{\circ} \mathrm{C}$.

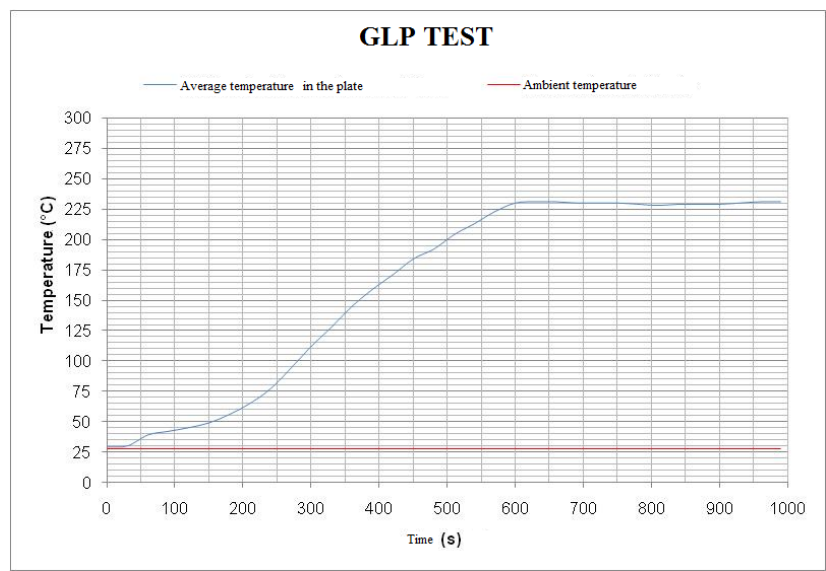

Fig. 8. Temperatures in the first test - LPG

For the second test, illustrated in Fig. 9, performed with $\mathrm{GLP}+10 \% \mathrm{BO} 25$, the plate was heated to a temperature of $281^{\circ} \mathrm{C}$ and the transient was $253^{\circ} \mathrm{C}$. The average temperature of the aluminum plate was higher than those obtained in the first test. The second test had an increase of $21.6 \%$ over the previous.

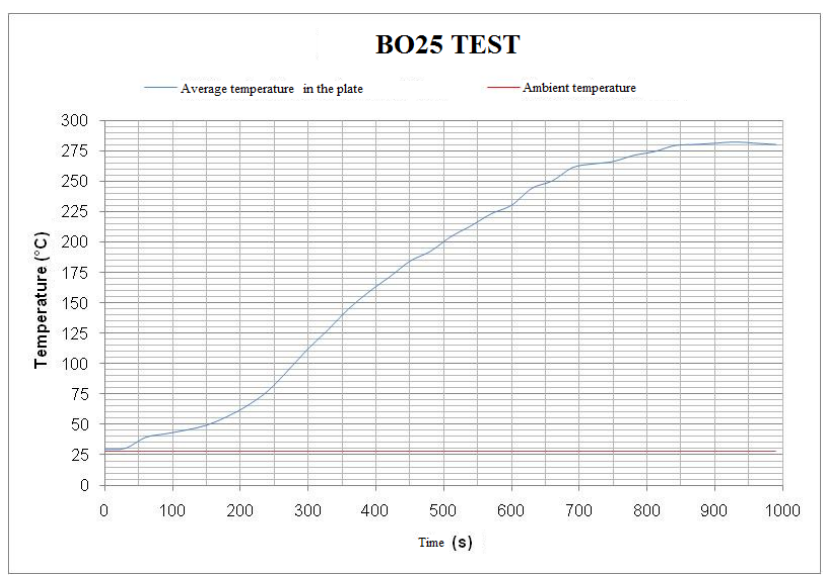

Fig. 9. Temperatures in the second test $-\mathrm{LPG}+10 \% \mathrm{BO} 25$

\section{GLP and BO25 Flow}

Table IV shows the results of measurements of fuel consumption for each assay. The flow of LPG has not varied in the two trials because there are separate nozzles for each fuel, and the adjustment of the manifold, responsible for the gas flame, remains the same.

Table IV. Hybrid fuel flow record

\begin{tabular}{|l|c|c|c|}
\hline \multicolumn{1}{|c|}{ Parameter } & $\begin{array}{c}\text { Test 01 } \\
\text { Only GLP }\end{array}$ & $\begin{array}{c}\text { Test } 02 \\
\text { GLP }+10 \% \\
\text { BO25 }\end{array}$ & Condition \\
\cline { 1 - 3 } $\begin{array}{l}\text { LPG gas flow } \\
(\mathrm{kg} / \mathrm{s})\end{array}$ & $8,51.10^{-5}$ & $8,51.10^{-5}$ & \\
\cline { 1 - 3 } $\begin{array}{l}\text { BO25 flow } \\
(\mathrm{kg} / \mathrm{s})\end{array}$ & - & $8,62.10^{-6}$ & $\begin{array}{c}\text { Steady } \\
\text { state }\end{array}$ \\
\cline { 1 - 3 } $\begin{array}{l}\text { Total flow } \\
(\mathrm{kg} / \mathrm{s})\end{array}$ & $8,51.10^{-5}$ & $9,38.10^{-5}$ & \\
\hline
\end{tabular}

Regarding of the fire modulation time control up/down, it was observed that over two thirds of the time of the test, the bench remained under a low heat and $1 / 3$ over high heat.

\section{E. Estimated Efficiencies Through the Results - 1st Law of Thermodynamics}

Table $\mathrm{V}$ shows the calculated data to estimate the performance of the infrared burner in accordance with conditions established in experimental trials. As mentioned in the methodology, was tried to study the heat transferred from the aluminum plate for the environment and thus achieve an analytical understanding of this performance from the calculation of the efficiencies of the 1st Law of Thermodynamics.

Table V. Estimated efficiencies of infrared burner

\begin{tabular}{|l|c|c|c|}
\hline Parameters & $\begin{array}{c}\text { Test } \\
01 \\
\text { LPG }\end{array}$ & $\begin{array}{c}\text { Test 02 } \\
\text { GLP }+ \\
10 \% \\
\text { BO25 }\end{array}$ & Conditions \\
\cline { 1 - 2 } $\begin{array}{l}\text { Lower heat value } \\
(\mathrm{kJ} / \mathrm{kg})^{(1)}\end{array}$ & 48.150 & 45.294 & \multirow{2}{*}{$\begin{array}{c}\text { Steady } \\
\text { state }\end{array}$} \\
\cline { 1 - 3 } $\begin{array}{l}\text { Fuel thermal } \\
\text { power }(\mathrm{kW})\end{array}$ & 4,10 & 4,25 & \\
\hline
\end{tabular}




\begin{tabular}{|l|c|c|c|}
\hline $\begin{array}{l}\text { Heat flow by } \\
\text { convection and } \\
\text { radiation }(\mathrm{kW})\end{array}$ & 0,36 & 0,47 & \\
\hline $\begin{array}{l}\text { Efficiency of first } \\
\text { law of } \\
\text { thermodynamics } \\
(\%)\end{array}$ & 8,7 & 11,0 & \\
\hline
\end{tabular}

(1) $:$ whereas $1 \mathrm{~kg}$ of fuel

Although the heating value of the hybrid fuel has decreased by $5.9 \%$ compared to LPG, the thermal power was increased by $3.6 \%$ due to an increase in mass of fuel injected.

The quantity of heat transferred by convection and radiation to the environment, increased by $31.2 \%$ because of rising temperatures involved in their trials. That ended up influencing the rise in values of efficiency of the infrared burner, resulting in useful energy gain of $26.7 \%$.

\section{Conclusions}

The experimental methodology adopted in the tests met the proposed objectives, enabling the achievement of concrete results about the performance of the infrared burner running on hybrid fuel GLP/BO25.

The values of viscosity and heating value of bio-oil from pyrolysis of biomass sawdust, held at UFRN's Laboratory of Biomass and Biofuel, were consistent with the data presented by Oasmaa and Czernik (1999)

The dilution increased by only $11 \%$ of the heating value of bio-oil, but allowed $75.4 \%$ decrease in fluid viscosity, improving atomization. Thus, these results provide consistent data for analysis of the parameters.

The injector nozzle designed to perform atomization of BO25 with compressed air met the objective. Visually there was no presence of coke in the ceramic matrix of the burner, thus proving that the atomization process was efficient.

When used $\mathrm{BO} 25$ that was stored for more than 15 days, it was observed that the nozzle clogged in some instances, indicating that the bio-oil, even diluted with absolute ethanol, showed polymerization reactions and problems of increase in its viscosity.

After the tests, it was possible the addition of $10 \%$ bio-oil diluted in the infrared burner used. This addition led the rise of temperature on the plate of $231^{\circ} \mathrm{C}$, obtained with the burn of $\mathrm{LPG}$, to $281{ }^{\circ} \mathrm{C}$ when combined with the atomization of $\mathrm{BO} 25$. This is due to improved oxidation of burning hybrid due to excess air in the atomization of bio-oil.

Rising temperatures involved in the tests allowed an increase of $31.2 \%$ in quantities of heat transferred by convection and radiation, plus a useful energy gain of $26.7 \%$, according to the elevation of the efficiency values of the infrared burner.
In the tests, with the addition of $\mathrm{BO} 25$ below $10 \%$ the injector nozzle designed clogged. While over $10 \%$, the problem was the clogging of the combustion chamber, due the precipitation of liquid fuel, causing flame return and flame below the ceramic substrate.

\section{Acknowledgements}

The authors would like to acknowledge Potigás and UFRN the support given to this work.

\section{References}

[1] Huber, G. W.; Iborra, S.; Coma, A.; "Synthesis of transportation fuels from biomass: chemistry, catalysis, and engineering." Chemical Reviews, 106, p.4044-4098. 2006.

[2] Peláez-Samaniego, M. R.; Garcia-Perez, M.; Cortez, L. B.; Rosillo-Calle, F.; Mesa, J.; "Improvements of brazilian carbonization industry as part of the creation of a global biomass economy." Renewable and Sustainable Energy Reviews, 12, n. 4, p. 1063-1086, 2008.

[3] Campos, A. C. M.; "Carvão de eucalyptus: efeito dos parâmetros da pirólise sobre madeira e seus componentes químicos e predição da qualidade pela espectroscopia NIR." Dissertação (Mestrado em Engenharia Ambiental). Universidade Federal de Lavras, Minas Gerais, 118 f, 2008.

[4] Qiang, L.; Wen-Zhi, L.; Xi-Feng, Z.; “Overview of fuel properties of biomass fast pyrolysis oils. Energy Conversion and Management", 50, p. 1376-1383, 2009.

[5] Faaij, A.; Walter, A.; Bauen, A.; Bezzon, G.; Rocha, J. D.; Moreira, J. R.; Craig, K. R.; Overend, R. P.; Bain, R. L.; "Novas tecnologias para os vetores modernos de energia de biomassa." Campinas: Editora da UNICAMP, Campinas, p.339-411, 2005.

[6] Tsai, W. T.; Lee, M. K. Chang, Y. M.; "Fast pyrolysis of rice straw, sugarcane bagasse and coconut shell in an induction-heating reactor." Journal of Analytical and Applied pyrolysis, 76, p.230-237, 2006.

[7] Howell, J. R.; "Combustion of hydrocarbon fuels within porous inert media." Prog. Energy Combustion Science, 22, p. 121-145, 1996.

[8] Diebold, J. P.; "A review of the chemical and physical mechanisms of the storage stability of fast pyrolysis bio-oils." National Renewable Energy Laboratory. 51p, 2000.

[9] Oasmaa, A.; Czernik, S.; "Fuel oil quality of biomass pyrolysis oils - state of the art for the end users." Energy \& Fuel, 13, p.914-921, 1999. 